\title{
CSÖVEK KERESZTMETSZET-SZÜKÜLÉSÉNEK MODELLEZÉSE ÉS REZGÉSDIAGNOSZTIKAI VIZSGÁLATA
}

\section{MODELING AND VIBRATION DIAGNOSTIC EXAMINATION OF THE INNER DIAMETER REDUCTION OF PIPES}

\author{
Kocsis Dénes ${ }^{1}$, Horváth Róbert ${ }^{2}$ \\ Debreceni Egyetem, Müszaki Kar, Környezet- és Vegyészmérnöki Tanszék, 4028 \\ Magyarország, Debrecen, Ótemetö utca 2-4; Telefon: +3652/415155-77827; \\ ${ }^{1}$ kocsis.denes@eng.unideb.hu \\ ${ }^{2}$ horobjan@gmail.com
}

\begin{abstract}
In this work model experiments and vibration diagnostic tests were performed on stainless steel and PVC pipes. Reduction in inner diameter of pipes, as a characteristic failure (for example limescale deposition) was modeled in the introduced test series. To this end, the different phases of deposition are artificially simulated in the model experiments. Characterization of the degradation of the pipes was performed by vibration based measurements.
\end{abstract}

Keywords: modeling, pipes, vibration diagnostic.

\section{Összefoglalás}

Ezen munkánkban rozsdamentes acél és PVC csöveken végeztünk modellkísérletet és rezgésdiagnosztikai vizsgálatokat. A kísérletsorozat során a csövek belső falára különböző vastagsággal vittünk fel anyagot, a csövek egyik jellemző tönkremenetelét, a keresztmetszet-szükülést (például vízkőlerakódás) modellezve. Az eltérő állapotú csöveken végzett rezgésdiagnosztikai vizsgálatok révén meghatároztunk olyan rezgésparamétereket, amelyek jellemzik a csövek degradációs állapotát.

Kulcsszavak: modell, csövek, rezgésdiagnosztika.

\section{Bevezetés}

A csövek tönkremenetelének egyik gyakori oka a belső falukra történő lerakódások következtében bekövetkező átmérő szükülés. Ezen kísérletsorozat során a belső átmérő csökkenésének modellezését valósítottuk meg és a különböző csőállapotokhoz tartozóan rezgésdiagnosztikai vizsgálatokat végeztünk. Célunk a cső állapotának roncsolásmentes módon történő felmérése volt rezgésparaméterek segítségével.

\subsection{Csövek rezgésdiagnosztikai vizs- gálata}

A csővezetékek az ipari rendszerek fontos elemei, és meghibásodásuk sok esetben jelentős anyagi és környezeti kárral jár. Az összes meghibásodás jelentős része $(>30 \%)$ a csővezetékek sérülésére, meghibásodására vezethető vissza [1], ennek megfelelően a terület egyre nagyobb figyelmet kap. Különböző statisztikai, mérési és számítási eljárások jelentek meg a szakirodalomban, amelyek célja a csővezetékek szivárgásának 
és törésének meghatározása, azok előrejelzése [2, 3].

Rezgés alapú diagnosztikai teszteket gyakran alkalmaznak anyagok és szerkezetek állapotának és meghibásodásának értékeléséhez. Az állapotfelmérésre és hibakeresésre alkalmas módszer az impulzusgerjesztés (impulse excitation of vibration, IEV), amely során a rezgésgerjesztés egy ütésszerü impulzus révén valósul meg. A gerjesztést követően a rezonanciafrekvenciák méréséből nyert információk használhatóak fel különböző célokra, mint például a dinamikus Young és a nyírási modulus meghatározására [4]. Szintén széles körben alkalmazott a repülési idő (time of flight, TOF) technika, amely alkalmazható például a csőfal elvékonyodásának megjelenítésére [5].

A sajátfrekvenciák meghatározása csővezeték rendszerek vizsgálata esetén is sok esetben képezik a kiértékelés alapját [6-9]. Korábbi munkák folyadékszállító csővezetékeket vizsgáltak transzfer-mátrix módszerrel és meghatározták a rendszer saját frekvenciáit [10, 11]. Laboratóriumi körülmények között is végeztek modellkísérleteket csővezeték rendszerek vizsgálatára, amely esetekben a sajátfrekvenciák értékelése szintén kiemelt fontosságú volt [12]. Szakirodalmi munkák alapján a rendszerek merevségének változása kimutatható a kísérletileg meghatározott sajátfrekvencia értékekben [13].

\section{Felhasznált anyagok és módsze- rek}

\subsection{Vizsgált anyag}

Vizsgálatainkat egy $89 \mathrm{~mm}$ külső átméröjü, $2 \mathrm{~mm}$ falvastagságú rozsdamentes acélcsövön végeztük el. (Aquaplus Kft. által használt csőtípus, Heat N $0416950 \mathrm{EN}$ 1.4541 TP 321 EN 10217-7 TC1 W1 CR, $88,9 * 2,0 \mathrm{~mm}$, gyártási idő: 2009.07.14, hegesztett rozsdamentes acélcső). Választásunk azért esett erre a csőre, mert ilyen mé- ret paraméterekkel rendelkező csőszakaszban végbemenő vízkőlerakódás okozott rendszeresen problémát több magyarországi város (Zalaegerszeg, Kistelek) geotermikus rendszerének esetében. Az általunk vizsgált cső teljes hossza $1115 \mathrm{~mm}$ volt.

A kísérletsorozatot megismételtük PVC alapanyagú csövön is (Pipelife Hungária Kft. gyártmányú, KM PVC-U nyomócső, SDR 33 PN6, 90*2,8 mm, extrudált cső), amelynek esetében szintén elöfordul lerakódások következtében történő belső átmérő csökkenés. A vizsgált PVC cső hossza megegyezett a rozsdamentes acélcső hoszszával.

\subsection{Felhasznált eszközök}

A mérésekhez két triaxiális érzékelőt (PCB 356A02) csatlakoztattunk egy Sinus Soundbook MK2 8LE 8 csatornás mérőrendszerhez, amelyen Samurai (SINUS Messetechnik $\mathrm{GmbH}$ ) univerzális szoftvercsomag segítségével végeztük el az adatok rögzítését és kiértékelését. A kísérletsorozathoz használtuk továbbá egy saját készítésü frekvenciagenerátort, illetve a méréseket egy E400 típusú esztergapadon végeztük. A csövek belső felületére történő anyagfelvitelt egy MVE 280M típusú esztergapadon történő forgatás során valósítottuk meg.

\subsection{Technikai megvalósítás}

A csövet a mérésekhez az esztergapadon bábok segítségével fogtuk meg. A befogásokhoz hosszirányban felhasított acélcső darabokat, illetve alájuk helyezett $3 \mathrm{~mm}$ vastagságú gumilapokat használtunk, a bábok ezeken keresztül fogták meg a csövet. A befogások közötti csőszakasz hossza 800 mm. A befogott cső vázlata az 1. ábrán látható.

A rezgésdiagnosztikai mérésekhez $2 \mathrm{db}$ triaxiális rezgésérzékelőt ragasztottunk a csőre az 1. ábrán látható elrendezés szerint. Az egyik érzékelő a 800 mm-es szakasz közepén került elhelyezésre el (acc. 1), míg 
a másik (acc. 2) az egyik befogáshoz közel (érzékelők távolsága $350 \mathrm{~mm}$ ).

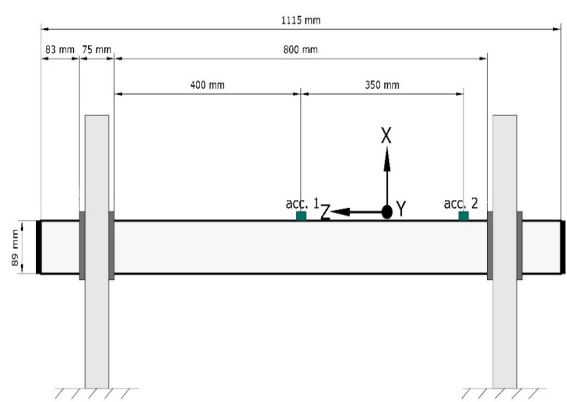

\section{1. ábra. A mérési rendszer vázlata}

A befogott csövön több helyen és több különböző irányból jelentkező impulzusgerjesztés mellett végeztük el a méréseket.

$\mathrm{Az}$ alapállapot mérése után cementesztrich réteg felvitelével szimuláltuk a belső átmérő csökkenését, amelyért felelős lehet például a csőfalon jelentkező vízkőképződés. A cementesztrich rétegek felvitele több lépésben történt, mindig újabb betonréteget kialakítva a csövön. A cementesztrichet a csőbe öntöttük, ezután megközelítőleg 1 órára esztergapadba fogva forgattuk. Onnan a csövet levéve a belső falára kirakódott réteget kötni hagytuk. A betonozáshoz a csövek végére helyeztük el az erre a célra kialakított müanyag dugókat, amelyek a mérések során végig a csőben voltak. A három betonozási szakaszhoz kapcsolódó átmérőváltozásokat és az esztergapadon alkalmazott forgási sebességeket tartalmazza az 1. táblázat.

1. táblázat. Betonozás következtében csökkenö belsö átmérö értékek és a réteg képzése során alkalmazott fordulatszám

\begin{tabular}{|c|c|c|c|c|}
\hline \multirow{2}{*}{ Réteg } & \multicolumn{2}{|c|}{$\begin{array}{l}\text { Ujj belső át- } \\
\text { mérö [mm] }\end{array}$} & \multicolumn{2}{c|}{$\begin{array}{c}\text { Forgatási seb. } \\
{[1 / \mathrm{min}]}\end{array}$} \\
\cline { 2 - 5 } & Acél & PVC & Acél & PVC \\
\hline 1. & 65 & 48 & 75 & 380 \\
\hline 2. & 50 & 38 & 150 & 380 \\
\hline 3. & 40 & 34 & 240 & 380 \\
\hline
\end{tabular}

\section{Kísérleti eredmények}

A kísérlet sorozat során sikeresen vittünk fel cementesztrich rétegeket a csövek belső falára. A különböző új belső átméröhöz kapcsolódóan elvégeztük a rezgésdiagnosztikai vizsgálatokat.

Az eredmények kiértékelése több szempont szerint is elvégezhetö, mint például a különböző típusú rezgések (longitudinális, kerületi) különböző modusaihoz tartozó sajátfrekvencia értékek változásának követésével. A belső átmérő értékének változása jól követhető a jellemző rezgésparaméterek csúcsértékeinek (rezgésgyorsulás: $\mathrm{a}_{\text {peak }}$, rezgéssebesség: $\mathrm{V}_{\text {peak }}$, rezgéselmozdulás: $\mathrm{d}_{\text {peak }}$ ) változásán keresztül. Az ugyanolyan gerjesztésre kapott rezgésparaméter átlagértékek láthatóak a 2. táblázatban.

2. táblázat. Jellemzö rezgésparaméter értékek egészre kerekitett átlagai és korrigált szórásai (SD) azonos gerjesztés mellett (acc. 1, x irány) (rozsdamentes acélcsö (A) és PVC cső (B) esetén, CE:cementeszrich réteg)

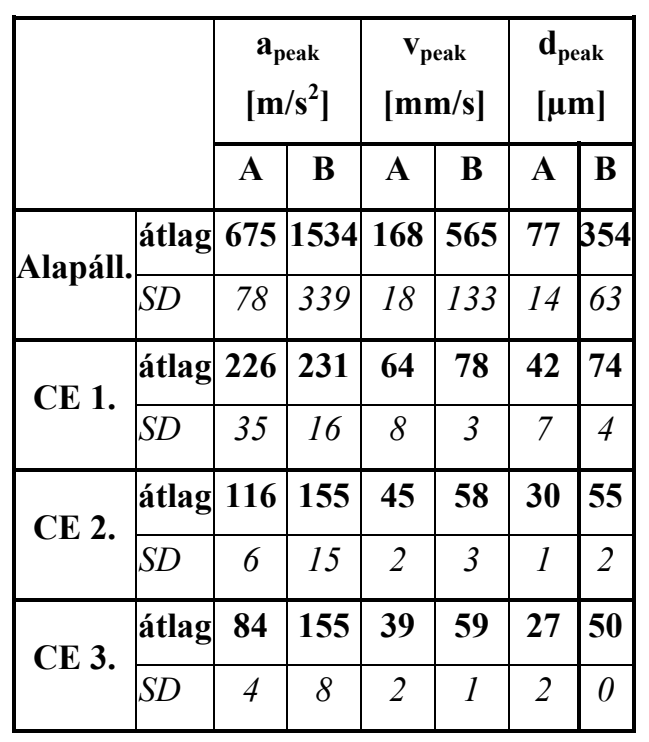




\section{Következtetések}

Jelen munkában két különböző anyagú csővezetéken végeztünk el modellkísérletet, amely során különbözö rétegvastagságban vittünk fel a belö falukra cementesztrich réteget. A különböző állapotokhoz tartozóan rezgésdiagnosztikai teszteket folytattunk.

A bemutatott rezgésdiagnosztikai módszerrel lehetőség nyílhat a csövek állapotának értékelésére, illetve figyelemmel követésére. Az általunk elvégzett modellkísérlet meglátásunk szerint nemcsak beltéri csövek esetén lehet hasznos, hanem sok esetben a földbe fektetett csövek viselkedését is jól követheti (feltárás nélküli csőfektetés, talaj tömörödés hiánya a földben lévő csőszakasz felett, stb.).

\section{Szakirodalmi hivatkozások}

[1] Drozyner P.: Determining the limits of piping vibration. Scientific Problems of Machines Operation and Maintenance 2011;46(1):97103.

[2] Simola K, Pulkkinen U, Talja H, Karjalainen-Roikonen P, Saarenheimo A.: Comparison of approaches for estimating pipe rupture frequencies for risk-informed inservice inspections. Reliab Eng Syst Saf 2004 APR;84(1):65-74.

[3] Li S, Wen Y, Li P, Yang J, Dong X, Mu Y.: Leak location in gas pipelines using crosstime-frequency spectrum of leakage-induced acoustic vibrations. J Sound Vibrat 2014 AUG 18;333(17):3889-3903.

[4] Raggio LI, Etcheverry J, Sánchez G, Bonadeo N.: Error analysis of the impulse excitation of vibration measurement of acoustic velocities in steel samples. Physics Procedia 2010 1/1;3(1):297-303.

[5] Lee J, Chong SY, Jeong H, Kong C.: A timeof-flight mapping method for laser ultrasound guided in a pipe and its application to wall thinning visualization. NDT E Int 2011 DEC;44(8):680-691.

[6]) Wang XH, Redekop D.: Natural Frequencies Analysis of Moderately-Thick and Thick Toroidal Shells. Procedia Engineering 2011;14(0):636-640.

[7] Saeed RA, Galybin AN, Popov V.: 3D fluidstructure modelling and vibration analysis for fault diagnosis of Francis turbine using multiple ANN and multiple ANFIS. Mech Syst Signal Proc 2013 JAN;34(1-2):259-276.

[8] Qing M, Zhang Jinghui, Luo Yushan, Wang Haijun, Duan Quan: Experimental studies of orifice-induced wall pressure fluctuations and pipe vibration. Int $\mathrm{J}$ Pressure Vessels Piping 2006 JUL;83(7):505-511.

[9] Yas MH, Samadi N.: Free vibrations and buckling analysis of carbon nanotubereinforced composite Timoshenko beams on elastic foundation. Int J Pressure Vessels Piping 2012 OCT;98:119-128.

[10] Li Shuai-jun, Liu Gong-min, Kong Weitao:. Vibration analysis of pipes conveying fluid by transfer matrix method. Nucl Eng Des 2014 JAN;266:78-88.

[11] Dai HL, Wang L, Qian Q, Gan J.: Vibration analysis of three-dimensional pipes conveying fluid with consideration of steady combined force by transfer matrix method. Appl Math Comput 2012 NOV 15;219(5):24532464.

[12] Semke WH, Bibel GD, Jerath S, Gurav SB, Webster AL.: Efficient dynamic structural response modelling of bolted flange piping systems. Int J Pressure Vessels Piping 2006 OCT;83(10):767-776.

[13] Mattheis A, Trobitz M, Kussmaul K, Kerkhof K, Bonn R, Beyer K.: Diagnostics of piping by ambient vibration analysis. Nucl Eng Des 2000 MAY;198(1-2):131-140. 